\title{
Demográfiai és szociál- pszichológiai hatások az életszínvonal minimális és ideális szintjének megítélésében
}

\section{Demographic and Socio-Psychological Effects in Judging the Minimum and Ideal Standard of Living}

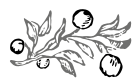

\section{Összefoglalás}

Egy uniós kutatás 26 tagállamban végzett vizsgálatot, melyben összehasonlító mutatószámokat hoztak létre az életszínvonalra vonatkozóan. Tanulmányunk alapötletét ez a kvalitatív kutatás adta. Felmerült ugyanis, hogy a megkérdezettek szociális és gazdasági helyzete erôsen moderálta, hogy egy adott nemzetben mit tekintenek „minimálisan elfogadhatónak” és „megengedhetônek” bizonyos jószágok és szolgáltatások esetében. Ennek megfelelóen az így kialakított fogyasztói kosarak nem feltétlenül tükrözik azt,

Dr. Minály NikoletT, egyetemi adjunktus, Szent István Egyetem (mihaly.nikolett@gtk.szie.hu); Dr. Komáromi Nándor, egyetemi docens, Szent István Egyetem (komaromi.nandor@gtk.szie.hu); RónaI RAMónA, Szent István Egyetem (ronai. ramona@gmail.com); DR. BRUdER EMESE, egyetemi adjunktus, Szent István Egyetem (bruder.emese@gtk.szie.hu). 
hogy mi az adott társadalomban a méltányos részvételhez szükséges és elengedhetetlen minimum-életszínvonal. A vágyott, minimális vagy elégséges életszínvonal kitûzése és megteremtése ugyanis számos tényezô függvénye. Véleményünk szerint fontosak a demográfiai tulajdonságok, de legalább ilyen meghatározó, hogy milyen személyiségjegyekkel, pszichológiai hatásokkal, és szociokulturális gyökerekkel rendelkezik az egyén. Az alábbi tanulmány ezekhez a tényezôkhöz kapcsolódó kutatási eredményeket tekinti át, illetve mutat be egy kapcsolódó, nôk körében végzett kvantitatív kutatást.

Journal of Economic Literature (JEL) kódok: I31, I38, H31, H53

Kulcsszavak: életszínvonal, háztartás, identitás

\section{Summary}

The EU carried out research in 26 Member States using comparative indicators on the standard of living. The qualitative research served as a basis of this paper, as it was suggested that the social and economic situation of the respondents might have had a significant impact on the concepts 'minimum acceptable' and 'affordable' in any given nation in terms of certain goods and services. Accordingly, the consumer baskets created this way do not necessarily reflect the required and inevitable minimum standard of living in the given society. As a matter of fact, setting and achieving the desirable, minimum or satisfactory standard of living depend on a lot of factors. In our opinion demographic characteristics are also important but the respondents' personality traits, psychological impacts and social and cultural background are also as important. Our paper reviews the research results on the topic and presents empirical research carried out with women.

Journal of Economic Literature (JEL) codes: I31, I38, H31, H53

Keywords: standard of living, households, identity

\section{ELMÉLETI HÁTtér}

Irodalmi elemzésünk során elsôsorban arra fókuszáltunk, milyen tényezôk határozzák meg az életszínvonalra vonatkozó elképzeléseket, illetve az azzal való elégedettséget. Így különös figyelmet kaptak a demográfiai tényezôk, az ebból fakadó heurisztikák és szociálpszichológiai hatások. A következô részben ezeket tekintjük át.

Életszinvonal, elégedettség és demográfiai tényezôk

Az „életszínvonal” a szótári meghatározás szerint: „Valamely társadalom, közösség (gazdasági, múvelôdési) létfeltételeinek, különbözó jövedelmének és fogyasztásának mértéke, foka” (Magyar értelmezô kéziszótár, 2003). A nemzetközi szakirodalomban az életkor és az életminôség összefüggése kapcsán ellentmondásos kutatási eredmé- 
nyek születtek. Néhány szerzó szerint az életkor és az életminóség között nincs kapcsolat, vagyis a fiatalok, a középkorúak és az idősek egyformán boldogok és elégedettek (Diener et al., 1997; Easterlin, 2001). Azonban olyan eredmények is születtek, miszerint az életkor és az életminôség U alakú görbét ír le, vagyis a fiatalok és az idôsek elégedettebbek, mint a középkorúak (Frey-Stutzer, 2002; Blanchflower-Oswald, 2001). Diener (1984) szerint a fiatalok több élvezetet találnak az életben, azonban az idósebbek pozitívabb képet festenek arról. A szerzó ezt azzal indokolja, hogy az emberek az életkor elôrehaladtával bölcsebbé válnak, és jobban alkalmazkodnak a megteremtett környezetükhöz. Azok között a kutatások között, amelyek az életminőség és az életkor között a lineáris összefüggést vizsgálták, a pozitív és a negatív összefüggésre utaló eredmény is megtalálható. Pozitív összefüggést talált például Horley és Lavery (1995); Sheldon és szerzôtársai (2005) azonban azt tapasztalták, hogy ez a pozitív összefüggés csak addig áll fenn, amíg az emberek elérik az ötvenéves életkort, ezután már nem kimutatható. Ugyanezt támasztja alá a KSH 2014-ben végzett magyarországi vizsgálata. A kutatás szerint a fiatal felnôttek a legelégedettebbek, és ez az elégedettség egészen 45-54 éves korig eltart, majd ezt követôen jelentősen csökken; érdekes eredmény, hogy a 16-64 évesek körében a nôk elégedettebbek. Más kutatások szerint az életkor és a szubjektív életminőség közti összefüggés iránya negatív (Lomranz et al., 1990; Koo et al., 2004). Koo és szerzôtársai azonban kiemelik, hogy az életminooség időskori csökkenése csak bizonyos esetekben áll fenn, mint például az alacsony iskolai végzettség, az élettárs hiánya, a rossz egészségi állapot.

Kopp és Martos (2011) magyarországi kutatásai szerint a szubjektív életminôség változásai nincsenek lineáris és egyirányú kapcsolatban a gazdasági növekedéssel, azaz nem feltétlenül igaz az, hogy a gazdasági fejlódéssel jóllét alakul ki egy társadalomban. Ha a gazdasági aktivitást vizsgáljuk, ott elmondható, hogy a munkahellyel rendelkezók közül a teljes munkaidóben dolgozók a legelégedettebbek az életkörülményeikkel, közülük is leginkább a vállalkozók elégedettsége a kiemelkedó. A munkahellyel nem rendelkezốk körében a tanulók rendelkeznek a legnagyobb elégedettséggel. A kutatás rávilágít arra is, hogy a legkevésbé elégedettek azok, akik nem rendelkeznek munkahellyel, számukra ez nemcsak gazdasági probléma, hanem az egyén pszichés, mentális állapotára is negatív hatással van. Az egészségi állapot kapcsán kimutatható, hogy eltérés van az egészségi állapot szubjektív és objektív megítélése között. Az életminôség megítélésével a szubjektív egészségi állapot áll kapcsolatban (Fekete, 2006). Utasi (2002) empirikus adatokkal igazolta, hogy az egyéneket körülvevô szociális háló, a társas kapcsolatok szolidaritása és a kapcsolatokon keresztül megnyilvánuló szeretetforrás elôsegíti a boldogság és elégedettség érzetének növekedését. Kimutatta továbbá, hogy a boldog embereknek kétszer annyi barátjuk van, mint a boldogtalanoknak. Lengyel és Janky (2003) is azt igazolták, hogy a társas kapcsolatok közül a barátok hiánya erôsen valószínúsíti a boldogtalanságot. Ennek további tárgyalása azonban nem tartozik vizsgálódási körünkbe. (A jólét mérésének elméleti alapjairól és problémáiról kitûnô összefoglalót nyújt Gébert, 2012.)

A közelmúltban egy uniós kutatás a tagállamok szegénységküszöbéhez kapcsolódóan végzett felmérést. A 26 tagállamban végzett, fókuszcsoportos vizsgálatot is tar- 
talmazó kutatás olyan társadalmi mutatószámokat próbált létrehozni, mely mentén az európai országok társadalmi helyzete jól összehasonlítható. Ezek a társadalmi mutatószámok azt jelzik, hogy mennyibe kerülnek bizonyos minimálisan elvárt és elégséges jószág- és szolgáltatáskosarak a különbözô országokban, és azt megengedhetik-e maguknak az ott élók. Ezt a jószág- és szolgáltatáscsomagot referencia-költségvetésnek nevezték el. (Ez megmutatja, hogy mi az a minimális bevétel, mellyel az egyén betöltheti szociális szerepeit, és egészségesen élhet.) Minimálisan elégséges feltételnek tekintették azt a szintet, mellyel „tisztességes” és teljes értékú szociális életet tud élni a személy, azaz gazdaságosan tudja vezetni a háztartását, és teljes jogú polgárként részt vehet a társadalomban. Ez utóbbi azt jelenti, hogy az ember képes a különbözô szociális szerepeinek eleget tenni - ilyen szerep lehet például a „szülő”, „rokon”, „barát”, „kolléga” vagy „szomszéd”. Egy jó szülônek például (gazdasági értelemben is) képesnek kell lennie megfelelôen nevelni a gyermekét, biztonságos gyermekkort biztosítva, hogy magabiztos felnôtté válhasson. Egy másik példa: annak érdekében, hogy az egyén ,jó baráttá” váljon, be kell fektetnie abba, hogy a barátokkal szórakozni mehessen, vagy meghívja óket az otthonába. Ahhoz tehát, hogy a különbözô szociális szerepeinket megfelelően töltsük be, egy minimális jövedelmi szint feltétlenül szükséges.

Összesen 25 tagállamban 75 fókuszcsoportos lekérdezést végeztek, melynek szereplői 30 és 50 év közötti fôvárosi, „egészséges” személyek, akik különbözô társadalmi és gazdasági háttérrel rendelkeztek. Négy hipotetikus háztartástípusra készítették el a beárazott kosarakat: 1. két gyermeket nevelô házaspárra; 2. két gyermeket egyedül nevelố szülốre; 3. egyedülálló nôre és 4. egyedülálló férfira (fốvárosi, jó egészségi állapotú emberek).

A fókuszcsoportos lekérdezés elôtt a teljes költségvetés különbözô részeinek kialakításán szakértôk dolgoztak. A táplálkozási szakemberek például egy kosarat dolgoztak ki az egészséges élelmiszerekre, valamint az azokból elkészíthetô ételekre vonatkozóan. A kiindulási elv az volt, hogy ezeknek a kosaraknak a segítségével „minimális” költségvetésból is egészségesen lehet táplálkozni, illetve hogy az egyes egyéneknek és családoknak gazdaságilag képesnek kell lenniük egészségesen táplálkozni, az ehhez szükséges anyagi javakat megteremteni. A kutatók beárazták a kiválasztott ételeket és a szükséges összetevôket, és az így kialakított kosarakat mint egyfajta bevásárlólistát lehetett értelmezni. A fókuszcsoportos lekérdezések legfóbb témája tehát az volt, hogy azonosítsák be az emberek azokat az elemeket (termékeket/szolgáltatásokat), melyek szükségesek a különböző szociális szerepek megfelelô megjelenítéséhez, továbbá határozzák meg, mennyi pénzre van szüksége a fentiekhez (pl. Budapesten) egy családnak (ImPROVE, 2015)?

Kutatásunk alapötletét tehát ez a kvalitatív kutatás adta. Véleményünk szerint ugyanis a fókuszcsoportban részt vevôk szociális és gazdasági háttere erôsen meghatározó arra nézve, mit tekintenek „minimálisan elfogadhatónak” és „megengedhetőnek”. Az így kialakított és beárazott jószág- és szolgáltatáskosarak nem feltétlenül tükrözik azt, hogy mi szükséges és elengedhetetlen az adott társadalomban való méltányos részvételhez (mely az uniós kutatás egyik legfontosabb célja volt). Feltételezésünk szerint 
ugyanis a már bemutatott tényezôkőn túl (életkor, nem, foglalkoztatottság stb.) a jövedelem és az „identitás” is meghatározza, hogy a megkérdezettek milyen életszínvonalat tartanak „ideálisnak”, „elfogadhatónak”, „elviselhetőnek”. A kérdéskörhöz kapcsolódóan továbbá óhatatlanul figyelembe kell vennünk nemcsak az elóbb említett sajátosságokat, hanem az azokból fakadó, a gondolkodást torzító mechanizmusokat is, melyek befolyásolják az ítéletalkotást: speciális módon egyszerúsítik le a problémákat, a logika helyett a szubjektív érzések és a sajátságos keretezések válnak dominánssá. A következó részben ezeket tekintjük át.

\section{Heurisztikák és szociálpszichológiai hatások}

Tversky és Kahneman kutatásai igazolják, az emberek előrejelzéseik során rendszerint nem követik a várható hasznossági számítások szabályait, illetve az előrejelzés mögött álló tények statisztikai törvényszerúségeit (Kahneman-Tversky, 1973:237). Ehelyett néhány alapvetố heurisztikus eljárást alkalmaznak az ítéletalkotásaik során. E heurisztikák olyan mentális múveletek vagy „rövid utak” (shortcuts), melyek bonyolult és kockázatos döntési helyzetekben leegyszerúsítik a problémát; a logika helyett a szubjektív érzések, előítéletek és hüvelykujjszabályok válnak dominánssá (Tversky-Kahneman, 1974; Kahneman-Slovic-Tversky, 1982; Kahneman-Tversky, 1996). A szerzópáros és követôik elméleteinek és kísérleteinek eredményeképp megszületett a kilátáselmélet, mely a racionalitástól, illetve a racionális várakozások diktálta magatartástól eltérô döntési mintákat azonosította.

Kahneman és Tversky egyik leglényegesebb felfedezése az értelmezési keretrendszerekhez kapcsolódik, és keretezésnek vagy „csomagolásnak” nevezték el. A „csomagolási” vagy „keretezési hatás” (framing effect) azt jelenti, hogy bizonytalan helyzetekben az információk adásának módja meghatározó hatással van az egyéni döntésekre. Például az információk mennyiségében jelentkezô különbségek, a probléma elôadásának módja vagy az opciók száma, amelyeket a döntéshozóknak felkínálnak, meghatározza, miként keretezi az egyén a problémát, s így milyen döntést hoz majd. A keretezési hatásnak számos alfaját azonosították, de jelen tanulmányban csak a „felidézési elôítélettel” foglalkozunk, mivel úgy gondoljuk, hogy az életszínvonal esetében ez az a keretezés, mely különös torzító erôvel bír (a három heurisztika egyike). A felidézési elôítélet (availability bias) kimondja, hogy az emberek a szokatlan, rendkívüli, látványos és személyesen tapasztalt eseményeket szisztematikusan túlértékelik, amikor döntést hoznak. Ezzel függ össze a dolgok, események szubjektív módon tulajdonított jelentôségének másik meghatározó tényezôje is. Azt, hogy egy adott jelenséget, eseményt mennyire gyakorinak ítélünk, attól tesszük függôvé, milyen könnyen hívjuk elô a memóriánkból. A gyakori eseményeket könnyebben tudjuk felidézni, és nagyobb gyakoriságot tulajdonítunk azoknak a jelenségeknek, amelyek valamilyen okból nagyobb hatást tesznek ránk, mint a közömbös, érdektelen eseményeknek (Hámori, 2003:788). Az életszínvonal esetében valószínúsíthető, hogy a jövőre vonatkoztatott elképzeléseket determinálja, milyen jelen/múltbeli gazdasági problémákkal küzd a környezetünk és mi magunk, valamint milyen információink vannak a lehetôségeinkrôl. 
Természetesen más torzító erejú, a vágyott, lehetséges életszínvonal kialakításában meghatározó pszichológiai hatások is érvényesülnek. Itt ezek közül csak három tényezôt veszünk górcsố alá: a „társas összehasonlítás” késztetését, az „arctudatosságot” és az „identitást” emelnénk ki.

Társas összehasonlítás. Az emberek rendszerint saját gazdagságukat többre értékelik, s ezáltal boldogabbak, ha helyzetüket másokhoz képest jobbnak látják. (Ezt „referenciabevétel” hipotézisnek is nevezik.) Tehát nemcsak az számít, mennyit keresünk, hanem az is, hogy másokhoz képest mennyit keresünk (sôt!). Fontos például, hogy a nemzeti átlagkeresethez viszonyítva mekkora a bérünk: minél inkább meghaladja az „átlagost”, várhatóan annál elégedettebbek vagyunk az életszínvonalunkkal. Persze a jövedelmünk okozta boldogságszint nemcsak ettôl függ, legalább ennyire számít, hogy mennyit keresnek a kollégáink, a szomszédjaink, a barátaink, a rokonaink (vagy legalábbis mit gondolunk arról, hogy mennyit keresnek azok az emberek, akikkel szeretjük összehasonlítani magunkat). Az emberek nagy része egyfajta rangsort alakít ki e tekintetben, s minél elôkelóbb helyen helyezi el magát, annál boldogabb, és annál jobb az önértékelése. Sốt, önmagunk ilyesfajta összehasonlítása és az ebbôl fakadó szubjektív „rangsorhely” erôsebb elôrejelzôje a boldogságszintnek, mint a tényleges kereset mennyisége.

Arctudatosság. Zhang azonban kutatásokkal bizonyítja, hogy azok az emberek, akik folyamatosan másokkal hasonlítják össze magukat, boldogtalanabbak. Eredményei szerint a pénz hatása a jólét érzésére elsôsorban attól függ, hogy az embernek mekkora a „másoknak való megfelelés igénye” (az ô elnevezésében „arctudatossága”). Mit is jelent ez pontosan? Egyfelől az egyén szociális státuszát a közösségen belül, másfelôl valamifajta vágyakozást, hogy jó színben tûnjünk fel mások elôtt. Ha az „arctudatosság” magas, akkor az illetô sokat törôdik azzal, hogy kedvezô legyen a szociális megjelenése, próbálja megtartani, fokozni és védeni a már kialakított képet. Két forrásból származhat az arctudatosság: személyes tulajdonságokból, melyek különleges eredményekhez vezetnek, illetve mások eloott jól megmutatható dolgokból, pl. egészség, pénz. A társas összehasonlítás és az arctudatosság tehát összefügg, éppen ezért a fejletlenebb piacgazdaságokban különleges szerepet játszanak a luxustermékek, melyek a versenyben való helytállást jelzik. Akinek magas az „arctudatossága”, inkább számon tartja majd a rangsorban elfoglalt helyét is, illetve inkább értékeli a pénzt; s ha van belóle, az a szubjektív jólét érzetét is növeli. Ha azonban az ilyen embereknek kevés pénzük van, sokkal boldogtalanabbak lesznek azoknál, akiknek ugyanannyi pénzük van, de másoknak kevésbé kívánnak megfelelni. Általában azt gondoljuk, ha egy kicsit több pénzünk lenne, boldogabbak lennénk, ám ez nem feltétlenül igaz. Amikor elérünk egy magasabb szintet, pillanatnyilag boldogabbak vagyunk, de aztán a megszokás és a társas összehasonlítás késztetése miatt újabb, magasabb igényszint jelenik meg az életünkben. Ezért általános, hogy minél több pénzünk van, annál többet akarunk. Persze árnyalja a képet a személyiség, azaz milyen kulturális háttérrel s ennek megfelelô arctudatossággal és önértékeléssel rendelkezünk.

Az identitás több tudományágban megjelenô fogalom, ma már nemcsak a pszichológiában, szociológiában fordul elô, hanem a közgazdaságtanban is felbukkant, mint 
gazdasági folyamatokat moderáló tényezô. Számos identitás létezik: etnikai, nemzeti, nyelvi, vallási, nemi osztályidentitás stb. Tanulmányunkban elsôsorban a szociális identitással foglalkozunk, mivel úgy gondoljuk, leginkább ez gyakorol hatást az életszínvonalra és a vágyott életminôségre. A szociális identitás fogalma Erving Goffman nevéhez köthetô, és a következóképpen definiálható: „....az egyéntôl várt viselkedést nemcsak a társadalmi szerepek befolyásolják, hanem a személyes érték és választások is, ilyen lehet a becsületesség, szépség stb. A legfontosabb kérdés az, hogy az adott személy milyen identitásokat, milyen identitásszerkezetet tart érvényesnek a maga számára” (Török, 2010). Doyal és Gough alapvetô célként az ember mindenfajta elnyomás és kiszolgáltatottság alóli felszabadítását fogalmazza meg, és ennek feltételeit keresi a szükségletkielégítés nézópontjából.

Alapszükségletként az egészséget és az autonómiát tartják. Úgy vélekednek, hogy a fizikai és mentális egészség együtt a legalapvetôbb emberi szükséglet, melynek kielégítése az egyén alapvető érdeke. Az alapszükséglet másik csoportja az egyéni azonossághoz (identitáshoz) vagy autonómiához kapcsolható. Megfogalmazásuk szerint ez az alkotó tudat alapszükséglete, az a képesség, mellyel a célokat és a célok eléréséhez szükséges stratégiákat megalkotjuk (Doyal-Gough, 1991).

Az identitás kialakulásával E. H. Erikson (1965; 1966a; 1966b) foglalkozott, aki úgy fogalmaz, hogy az identitás az ifjúkor végén alakul ki, amikor a már megszerzett képességek aktiválódnak, és betöltik a megfelelô szociális szerepeket. Berger és Luckmann (1998) meghatározása szerint az egyén identitása az elsôdleges szocializációs folyamatban az objektív valóság meghatározott metszetének közvetítésével aktiválódik, és ezt követôen már nagyon nehezen módosítható. Más szempontból is vizsgálták, társadalmi meghatározottságot tulajdonítva neki: „... a szervezet, az egyéni tudat és a társadalmi struktúra összjátékából termelt identitás reagál a fennálló struktúrára, megôorzi, megváltoztatja, vagy akár újjá formálja... Az identitástípusok viszont egészükben társadalmi termékek, objektív valóság viszonylag stabil elemei, noha stabilitásuk foka természetesen ismét társadalmilag van meghatározva” (Berger-Luckmann, 1998:237-239).

Ahhoz, hogy a társadalomban az identitásunknak megfelelố szerepet be tudjuk tölteni, figyelembe kell venni az egyéni befolyásoló tényezôket, továbbá az intézményi, fizikai, kulturális és gazdasági körülményeket. A megfeleló társadalmi részvételhez szükség van arra, hogy a különbözô társadalmi pozíciók elérhetôvé váljanak. Az Európai Bizottság finanszírozásával, az Antwerpeni Egyetem közremúködésével megvalósult kutatásban, amelyben a referencia-költségvetést vizsgálták, különbözô társadalmi kategóriákat állapítottak meg. Ezek a kategóriák nôk esetében a következôk: anya; diák; saját vállalkozást, céget vezetô személy; háztartásbeli; valamilyen társulás / szervezet tagja (lehet gazdasági, sport, nemi identitáshoz stb. kapcsolódó); független nô; feleség; állampolgár; barát. Ezen társadalmi pozíciókat a hivatalos társadalmi elvárásoknak és az EU-tagállamok nemzetközi irányelveinek megfelelôen alakították ki, figyelembe véve továbbá a nélkülözhetetlen emberi szükségleteket is. Kutatásunkban mi is e besorolást vettük alapul.

A fent vázolt összefüggések és tapasztalataink mentén a következó hipotézisek rajzolódtak ki: 
H1: Az életkor növekedésével az életszínvonalra vonatkozó elvárások növekednek, míg a nyugdíjkorhatárhoz közelítve ezek csökkenô tendenciát mutatnak.

H2: A fơvárosban lakók a „nagyon szúkös” és a „nagyon jó” életszínvonal megteremtéséhez magasabb összegeket társítanak, mint a vidéken lakók.

H3: Az erôsebb nối identitással rendelkezốk alkati sajátosságaiknál fogva alacsonyabb összegeket társítanak a „nagyon szúkös” és a „nagyon jó” életszínvonalhoz, mint akiknek az elsôdleges identitását más határozza meg.

H4: Ahogy növekszik a háztartásban élôk száma, úgy monoton csökken annak megítélése, hogy mennyi pénzből tud „szúkösen” megélni egy fő.

H5: Ahogy növekszik a háztartásban élôk száma, úgy monoton csökken annak megítélése, hogy mennyi pénzból tud „nagyon jól” megélni egy fô.

\section{EMPIRIKUS KUTATÁS}

A kutatásunkban való részvétel önkéntesen történt, a megkérdezés módja az online kérdôív volt, mely kitöltésére 2017 márciusában került sor. A kérdőívet összesen 195 nô töltötte ki. A kérdôívben többféle kérdéstípus szerepelt: egyszerú választás, válaszmátrix, rangsorolás és képhez kapcsolódó, rövid válasz. A kérdôív más kérdéscsoportokat is érintett, alapul véve az antwerpeni kutatás eredményeit, de itt csak az életszínvonalhoz kapcsolódó eredményeket ismertetjük. Az eredményeket SPSS programmal értékeltük ki.

Elsôsorban arra voltunk kíváncsiak - a már ismert demográfiai hatásokat is számba véve -, hogy a szociális környezet és az identitás miként befolyásolja az egyéni vélekedést arról, mekkora összeg jelöli a „nagyon szúkös”, a „szerény”, az „átlagos”, a „jó” és a „nagyon jó” életszínvonalat. A háttérkoncepció tehát az volt, hogy annak megítélése, mennyi pénzre van szüksége egy háztartásnak, erôsen függvénye annak, hogy az illetô hány fôs háztartásban él, milyen jövedelemmel rendelkezik, illetve milyen identitáskategóriájú. Vélekedésünk szerint ezek a tényezók meghatározzák a „reprezentatív heurisztikákból” fakadó kognitív torzításokat, azaz a szükségletek nagyságának észlelését.

A „Hány fôs háztartásban élnek?” kérdésre a következố válaszokat kaptuk (kiemeltük a három fontos, nagyobb elemszámú csoportot): 1. Egyedül él (25 fô); 2. Kétfôs háztartásban (69 fô); 3. Négyfôs háztartásban (35 fô). Eredményeink szerint, ahogy növekszik a háztartásban élôk száma, úgy monoton csökken annak megítélése, mennyi pénzből tud megélni egy fô. Míg például egy egyedül élő átlagosan 125 ezer Ft-ot jelölt meg arra a kérdésre: „Mekkora összegre lenne szüksége egy olyan háztartásnak, mint az Öné ahhoz, hogy »nagyon szúkös« életszínvonalon megéljen?”, addig egy négyfôs háztartásban élő ugyanerre a kérdésre átlagosan, egy fôre vetítve, 54 ezer Ft-ot válaszolt. Egy egyedül éló átlagosan 483 ezer Ft-ot jelölt meg arra a kérdésre: „Mekkora összegre lenne szüksége egy olyan háztartásnak, mint az Öné ahhoz, hogy »nagyon jó« életszínvonalon megéljen?”, addig egy négyfôs háztartásban élô ugyanerre a kérdésre átlagosan, egy fôre vetítve, 150 ezer Ft-ot mondott. Tehát egy egyedülálló, ha szúkös feltételekrôl gondolkozik, nagyjából dupla összeget jelöl meg a négyfôs családban élôhöz képest. Ugyanakkor, ha engedjük, hogy 
meglendüljön az életszínvonalról alkotott fantázia, az egyedülálló már több mint háromszoros összeget mond. A jelenség hátterében feltételezésünk szerint az áll, egy családi kötöttségek nélkül élô embernek (hiszen nem tartozik felelôsséggel a családtagjai iránt, kevésbé szokott hozzá a mindennapi anyagi megosztáshoz, hogy ne csak magát vegye figyelembe, amikor a havi bevételét felosztja a kiadások között) kevésbé korlátozott a fantáziája az anyagi lehetôségeit illetôen is. Míg az, aki családban él, hozzászokik a korlátokhoz, és ahhoz, hogy megossza az idejét a munkája, családja és különbözó feladatok között, s ennek következtében korlátoltabban gondolkozik az anyagi lehetôségekrôl is. A különbség hátterében természetesen ott bújik az a racionális magyarázat is, hogy míg egy egyedül élőnek a teljes háztartása rezsiköltségét egyedül kell fedeznie, addig egy négyfős háztartásban ugyanez több részre oszlik. Ez különösen fontos lehet azokban a háztartásokban, ahol a lakhatás költsége a bevételek tetemes százalékát viszi el.

1. táblázat: Egy életszínvonalhoz szükséges becsült összeg és a háztartás nagyságának összefüggése (Háztartásának havonta mekkora összegre lenne szüksége [nettó Ft, egy före], hogy a megadott életszinvonalon megéljen?)

\begin{tabular}{l|c|c|c}
\hline & $\begin{array}{c}\text { Nagyon szúkös } \\
\text { életszínvonal } \\
\text { (Sig. 0,000) }\end{array}$ & $\begin{array}{c}\text { Átlagos } \\
\text { életszínvonal } \\
\text { (Sig. 0,000) }\end{array}$ & $\begin{array}{c}\text { Nagyon jó } \\
\text { életszínvonal } \\
\text { (Sig. 0,000) }\end{array}$ \\
\hline Egyedül él & 125000 & 225000 & 483000 \\
\hline Kétfós háztartás & 78000 & 133000 & 255000 \\
\hline Négyfös háztartás & 54000 & 83000 & 150000 \\
\hline
\end{tabular}

Megjegyzés: Statisztikai módszer: varianciaanalizis. A táblázatban az érthetôség kedvéért az értékeket ezer Ft-ra kerekitettük, a számítások természetesen pontos értékekkel történtek

Forrás: Saját kutatás

Az identitás és életszínvonalbeli kilátások (alsó/felsố határok) között is érdekes összefüggések rajzolódnak ki. Az identitáshoz kapcsolódó kérdést komplexitása miatt csak 70-en válaszolták meg, így csak ilyen kis elemszámmal tudtunk dolgozni az identitáshoz kötôdô hipotézisek esetében. A tíz identitáskategóriát végül két nagyobb csoportba rendeztük: a „nôi szerepekhez kapcsolódó” (anya, háziasszony, feleség) és az „egyéb” (diák, állampolgár, testvér, barát, független, vezető, valamilyen társulás, szervezet tagja) identitáscsoportba. Ha az identitáskategóriákra vonatkozó, leginkább jellemzô válaszokat nézzük, a következô sorrend alakul ki: a leggyakrabban bejelölt identitáskategória az „anya” volt, ezt követte a „független nő”, harmadik helyen pedig a „barát” (összesen 7-en) szerepelt.

Ezt követôen megnéztük, hogy a „nôi szerepekhez kapcsolódó” és az „egyéb” csoport között van-e különbség a tekintetben, milyen becsléseket tettek arra vonatkozóan: „Mekkora összegre lenne szüksége a háztartásának ahhoz, hogy nagyon szúkös életszínvonalon/szerényen/átlagosan/jól, illetve »nagyon jó « életszínvonalon megéljen?” Azt vártuk, hogy az erôsebb nôi identitású csoport, alkati sajátosságainál fog- 
va, kisebb összegeket jelöl meg, mint a másik csoport. Eredményeink szerint minden megjelölt életszínvonal esetében a nôi identitású válaszadók alacsonyabb összegeket adtak meg, mint a nem nôi identitású csoport. Nagyon szúkös életszínvonal esetében a nói identitásúak 147 ezer, a többiek 171 ezer Ft-ot adtak meg. A „nagyon jó” életszínvonal esetében 498 ezer és 540 ezer Ft jelentette az átlagot. Ennek hátterében valószínúleg az áll, hogy a magyar háztartások többségében a nôk kezelik a pénzügyeket, így ók „földhözragadtabban” gondolkoznak a minimumról, illetve az esetleges lehetôségekrôl is. Ehhez képest a KSH tájékoztatója szerint 2017 januárjában nemzetgazdasági szinten az átlagos nettó kereset 182 ezer Ft volt. (Fontos tudni azonban, hogy a fôvárosi és vidéki átlagkeresetek között jelentôs különbség mutatkozik. A fôvárosi dolgozók átlagosan 50\%-kal többet keresnek, mint a vidéki emberek, így természetesen a kapcsolódó lehetséges keresetekrôl/életszínvonalról is eltérô gondolkodás jellemzi a két csoportot.)

A valóság, a lehetôségek keretezését (hogyan értelmezzük az eseményeket, a lehetôségeket stb.) tehát meghatározza az identitás. Érdekes arra is figyelni, hogy a nôi és nem nôi identitású csoportok milyen egyéb észlelési különbségeket mutatnak az általunk vizsgált gazdasági kérdésekben. Legelôször azt néztük meg, van-e jellemzô jövedelmi különbség a nôi és nem nôi identitású csoport között, illetve hogy a pénzügyi attitúdjükben különböznek-e. Ezt egy pénzügyiattitúd-skálával - MAS - elemeztük (Roberts-Sepulveda, 1999). Az egy főre jutó havi nettó jövedelem alapján nincs szignifikáns különbség, de megmutatkozik az a tendencia, hogy a nem nói identitású csoport havi nettó jövedelme magasabb. A pénzügyi attitúdökben kevésbé mutattak különbséget a nôi és nem nôi identitású válaszadók, ha a nagyobb kategóriák szerint vizsgáltuk óket. Ha azonban a kategóriák egyes itemeit nézzük, már találhatók szignifikáns különbségek. A „Rendszeresen vadászom az akciókat” (Sig. 0,008), „Gondterhelt vagyok, ha pénzrôl van szó” (Sig. 0,039), „Sokszor automatikusan gondolom, hogy valamit nem engedhetek meg magamnak, még akkor is, ha ez nem igaz” (Sig. 0,007) itemek esetében a nôi identitásúak az elóbbi állításokkal kapcsolatban szignifikánsan inkább egyetértettek. Ebből következtethetôen a szorongás, a gondterheltség a pénzügyekkel kapcsolatban inkább jelen van az életükben, s talán ezzel is magyarázható, hogy az életszínvonalra vonatkozó kérdésekben alacsonyabb összeghatárokat jelöltek.

Demográfia. Miután ezek az összefüggések kirajzolódtak, kíváncsiak voltunk, hogy a gondolkodás ily módon való helyzet adta determinációja („korlátok között” vagy anélkül hoz ítéletet az egyén) miként jelenik meg egyéb demográfiai jellemzók függvényében. Így megvizsgáltuk a kor, a lakhely, a családi állapot hatását is. Az életkori összehasonlítás esetében mutatkoznak meg a legerôsebb szignifikáns különbségek. Négy korcsoportot határoztunk meg (2. táblázat), és minden életszínvonal-kategóriában ugyanaz a tendencia figyelhetố meg: az elsố három kategóriában monoton nô, az utolsó kategóriában pedig visszaesik az életszínvonalhoz kapcsolódó átlagos jövedelmek becslése. A táblázatból jól látható, hogy az életkor növekedésével, a nyugdíjkorhatárhoz közelítve a szükségletek, elvárások és kilátások növekednek, míg 50 év fölött ezek csökkenố tendenciát mutatnak. 
Mihály Nikolett - Komáromi Nándor - Rónai Ramóna - Bruder Emese: Demográfiai...

2. táblázat: Egy életszínvonalhoz szükséges becsült összeg és az életkor összefüggése

(Háztartásának havonta mekkora összegre lenne szüksége [nettó Ft], hogy a megadott életszinvonalon megéljen?)

\begin{tabular}{l|c|c|c}
\hline & $\begin{array}{c}\text { Nagyon szúkös } \\
\text { életszínvonal } \\
\text { (sig. 0,008) }\end{array}$ & $\begin{array}{c}\text { Átlagos } \\
\text { életszínvonal } \\
\text { (sig. 0,002) }\end{array}$ & $\begin{array}{c}\text { Nagyon jó } \\
\text { életszínvonal } \\
\text { (sig. 0,006) }\end{array}$ \\
\hline $\mathbf{1 8 - 2 5 ~ e ́ v ~}$ & 137000 & 230000 & 445000 \\
\hline $\mathbf{2 6 - 3 5}$ év & 184000 & 280000 & 543000 \\
\hline $\mathbf{3 6 - 5 0}$ év & 205000 & 336000 & 626000 \\
\hline $\mathbf{5 0}$ év felett & 152000 & 268000 & 520000 \\
\hline
\end{tabular}

Megjegyzés: Statisztikai módszer: varianciaanalizis. A táblázatban az érthetôség kedvéert az értékeket ezer Ft-ra kerekitettük, a számítások természetesen pontos értékekkel történtek

Forrás: Saját kutatás

A lakhely esetében azt vizsgáltuk, vajon van-e hatása a fốvárosi életformának arra, hogy a megkérdezettek milyen összegeket tartanak szükségesnek a „nagyon szúkös” és a „nagyon jó” életszínvonal megteremtéséhez. Nyilvánvalóan, akik egy magasabb életszínvonalon élnek, más perspektívákban gondolkoznak, mint akik szúkös feltételek között. Ezt igazolják a következô számok is. Budapesten és Pest megyében a 100 megkérdezett közül 59-en mondták azt, hogy 150 ezer Ft feletti az egy fŏre jutó havi jövedelmük (59\%), míg vidéki településen 91 főboól 52-en 150 ezer Ft alatti jövedelmet jelöltek meg (57\%). Az eltérés szignifikáns (Sig. 0,018).

3. táblázat: Havi jövedelem (Ft, egy före, nettó) és a lakhely összefüggése

\begin{tabular}{l|c|c|c}
\hline & $\mathbf{1 5 0}$ ezer Ft alatt & $\mathbf{1 5 0}$ ezer Ft felett & Összesen \\
\hline Budapest és Pest megye & $\begin{array}{c}41 \text { fó } \\
(41 \%)\end{array}$ & $\begin{array}{c}59 \text { fó } \\
(59 \%)\end{array}$ & 100 fó \\
\hline Vidéki település & $\begin{array}{c}52 \text { fó } \\
(57 \%)\end{array}$ & $\begin{array}{c}39 \text { fó } \\
(43 \%)\end{array}$ & 91 fó \\
\hline
\end{tabular}

Megjegyzés: Statisztikai módszer: Khi-négyzet próba

Forrás: Saját kutatás

Jövedelem. Eredményeink szerint a legmagasabb jövedelmi sávba (egy fốre jutó jövedelem magasabb, mint 250 ezer Ft) tartozók markánsan eltérnek az alacsony jövedelmi sávba tartozó megkérdezettektôl (egy fóre jutó jövedelem alacsonyabb, mint 150 ezer Ft) a tekintetben, hogy havonta mekkora összeg lenne szükséges számukra, hogy „nagyon szúkös”, illetve „nagyon jó” életszínvonalon megéljenek. A magasabb jövedelmúek jelentôsen magasabb összegeket határoznak meg. A „nagyon szúkös” kategóriában átlagosan 84 ezer Ft-ot, míg a „nagyon jó” kategóriában 282 ezer Ftot jelöltek meg. Ehhez képest az alacsonyban a „nagyon szúkös” életszínvonalat 73 
ezer Ft-ban jelölték meg, a „nagyon jó” színvonalra pedig 228 ezer Ft-ot adtak meg átlagban. A legmagasabb fizetési kategóriába esôk (350 ezer Ft felett) a „nagyon szúkös” életszínvonalnak megfelelố nettó összegszükségletet 222500 Ft-ban, a „nagyon jó” életszínvonalat megtestesítô összeget pedig 734 ezer Ft-ban látják.

\section{ÖSSZEFOGLALÁS}

A bevezetôben ismertetett, széles körú európai uniós kutatás az életszínvonalat meghatározó tényezôket vizsgálta, és fogyasztói kosarakat alakított ki, amit az adott országban „minimálisan elfogadhatónak”, „megengedhetônek” minôsítettek a fókuszcsoportos beszélgetésbe bevont személyek. Ez a kvalitatív kutatás is, de korábbi hazai és nemzetközi vizsgálatok is rámutattak, hogy a szubjektív életminôséget, az érzékelt életszínvonalat sok személyes és környezeti tényezô befolyásolja.

Jelen kutatásunk célja az irodalomból ismert hatótényezôk kvantitatív jellemzése volt. Eredményeink szerint elmondható, hogy a jövôbeli életszínvonalra vonatkozó elképzelések és elvárások - legyen az a minimum vagy a vágyott maximum - erôsen függnek nemcsak az egyén demográfiai jellemzôitôl, hanem szociálpszichológiai jellemzőitől és identitásától is. Ezek a tényezôk azonban kéz a kézben járnak. A háztartásban élók száma, a lakhely, a jövedelmi viszonyok természetes módon meghatározzák az egyén gondolkodási keretét - így kognitív heurisztikáit is -, s befolyással vannak az identitására is. Kutatásunk a korábbi eredményeket is egyértelmúen megerôsítette: az életkor növekedésével, a nyugdíjkorhatárhoz közelítve a szükségletek, elvárások és kilátások növekednek, míg 50 év fölött ezek csökkenô tendenciát mutatnak.

Kutatásunkkal elsôsorban arra szerettük volna felhívni a figyelmet, hogy amikor embereket a megélhetésükhöz kapcsolódó elképzelésükrôl, vágyaikról kérdezünk, fontos figyelembe venni az általunk vizsgált tényezóket is. Úgy véljük, hogy indokolt lenne nagy mintán, ismételt módon, kvantitatív eszközökkel megbízhatóan mérni ezeket az összefüggéseket, részben a döntéshozók támogatására, részben a társadalmi folyamatok dinamikájának meghatározására.

\section{FELHASZNÁLT IRODALOM}

Berger, Peter L. - Luckmann, Thomas (1998): A valóság társadalmi felépítése. Tudásszociológiai értekezés. Jószöveg Múhely, Budapest.

Blanchflower, David G. - Oswald, Andrew J. (2001): Well-Being over Time in Britain and the USA. Warwick Economic Research Papers, No. 616.

Diener, Ed (1984): Subjective Well-being. Phsychological Bulletin, Vol. 95, No. 3, 542-575, https://doi. org/10.1037//0033-2909.95.3.542.

Diener, Ed - Suh, Eunkook - Oishi, Shigehiro (1997): Recent Findings on Subjective Well-Being. Indian Journal of Clinical Psychology, Vol. 24, No. 1, 25-41.

Doyal, Len - Gough, Ian (1991): A Theory of Human Need. Guilford, New York.

Easterlin, Richard A. (2001): Income and Happiness: Towards a Unified Theory. The Economic Journal, Vol. 111, No. 473, 465-484, https://doi.org/10.1111/1468-0297.00646.

Erikson, Erik H. (1965): Childhood and Society [1950]. In: Kindheit und Gesellschaft. Klett, Stuttgart. 
Erikson, Erik H. (1966a): Growth and Crisis of the "Healthy Personality" [1950]. In: Identität und Lebenszyklus. Ed. Erik H. Erikson, Suhrkamp Verlag, Frankfurt am Main, 55-122.

Erikson, Erik. H. (1966b): The Problem of Egon Identity [1956]. In: Identität und Lebenszyklus. Ed. Erik H. Erikson, Suhrkamp Verlag, Frankfurt am Main, 123-212.

Fekete Zsuzsa (2006): Életminôség. Koncepciók, definíciók, kutatási irányok. In: A szubjektív életminőség és forrásai. Biztonság és kapcsolatok. Szerk. Utasi Ágnes, MTA Politikatudományi Intézete, Budapest, 277-309.

Frey, Bruno S. - Stutzer, Alois (2002): Happiness and Economics. Princeton University Press, Princeton-Oxford.

Gébert Judit (2012): A jólét mérésének elméleti alapjai és problémái. In: Regionális innovációs képesség, versenyképesség és fenntarthatóság. Szerk. Bajmócy Zoltán, Lengyel Imre, Málovics György, JATEPress, Szeged, 303-317.

Goedemé, Tim et al. (eds.) (2015): Pilot Project for the Development of a Common Methodology on Reference Budgets in Europe. Universiteit Antwerpen.

Hámori Balázs (2003): Kísérletek és kilátások. Daniel Kahneman. Közgazdasági Szemle, 50. évf., 9. sz., 779-799.

Horley, James - Lavery, J. John (1995): Subjective Well-Being and Age. Social Indicators Research, Vol. 34, No. 2, 275-282., https://doi.org/10.1007/bf01079200.

ImPROVE (2015): WP13 Reference budgets. TÁRKI, Budapest.

Kahneman, Daniel - Slovic, Paul - Tversky, Amos (eds.) (1982): Judgement under Uncertainty: Heuristics and Biases. Cambridge University Press, New York, https://doi.org/10.1017/cbo9780511809477.

Kahneman, Daniel - Tversky, Amos (1973): On the Psychology of Prediction. Psychological Review, Vol. 80, No. 4, 237-251, https://doi.org/10.1037/h0034747.

Kahneman, Daniel - Tversky, Amos (1984): Choices, Values, and Frames. American Psychologist, Vol. 39, No. 4, 341-350, https://doi.org/10.1037//0003-066x.39.4.341.

Kahneman, Daniel - Tversky, Amos (1996): On the Reality of Cognitive Illusions. Psychological Review, Vol. 103, No. 3, 582-591, https://doi.org/10.1037//0033-295x.103.3.582.

Koo, Jasook - Rie, Juil - Park, Kunseok (2004): Age and Gender Differences in Affect and Subjective WellBeing. Geriatrics and Gerontology International, Vol. 4, No. 1, 268-270, https://doi.org/10.1111/j.14470594.2004.00224.x.

Kopp Mária - Martos Tamás (2011): A magyarországi gazdasági növekedés és a társadalmi jóllét, életminóség viszonya. Magyar Pszichofiziológiai és Egészséglélektani Társaság, http://ess.tk.mta.hu/wp-content/uploads/2013/04/kopp_gazdasagi_novekedes.pdf.

Lengyel György - Janky Béla (2003): A szubjektív jólét társadalmi feltételei. Esély, 14. évf., 1. sz., 3-25.

Lomranz, Jakob et al. (1990): Subjective Well-being and its Domains across Different Age Groups: an Israeli Sample. Aging, Vol. 2, No. 2, 181-190, https://doi.org/10.1007/bf03323915.

Pomázi Gyöngyi (szerk.) (2003): Magyar értelmezố kéziszótár. Akadémiai Kiadó, Budapest.

Roberts, James - Sepulveda, Cesar J. (1999) Demographics and Money Attitudes: A Test of Yamauchi and Templer's Money Attitude Scale in Mexico. Personality and Individual Differences, Vol. 27, No. 1, 19-35, https://doi.org/10.1016/s0191-8869(98)00241-4.

Sheldon, Kennon M. et al. (2005): Doing One's Duty: Chronological Age, Felt Autonomy, and Subjective Well-Being. European Journal of Personality, Vol. 19, No. 2, 97-115, https://doi.org/10.1002/per.535.

Török Csilla (2010): Identitástudat és egyenruha. Az Egyesült Államok, Franciaország és Magyarország mai katonai egyenruháinak interkulturális összehasonlítása. BGF, Budapest, http://elib.kkf.hu/edip/D_15187.pdf.

Tversky, Amos - Kahneman, Daniel (1974): Judgment Under Uncertainty: Heuristics and biases. Science, Vol. 185, No. 4157, 1124-1131.

Utasi Ágnes (2002): A bizalom hálója. Mikrotársadalmi kapcsolatok, szolidaritás. Új Mandátum, Budapest.

Veenhoven, Ruut (2003): Happiness. The Psychologist, Vol. 16, No. 3.

Zhang, Xin-An - Cao, Qing (2010): For Whom Can Money Buy Subjective Well-being? The Role of Face Consciousness. Journal of Social and Clinical Psychology, Vol. 29, No. 3, 322-346, https://doi.org/10.1521/ jscp.2010.29.3.322. 